\title{
Analisis Implementasi Akad Salam Pada Perusahaan Hope Apparel Clothing Di Kabupaten Jombang
}

\author{
Yassindya Salwa \\ Universitas Islam Negeri Sunan Ampel Surabaya \\ ysalwa123@gmail.com
}

\begin{abstract}
Salam contracts at the moment have been implemented in different ways, namely using an online system or based on a network. Many companies implement this contract, but it is still unknown whether the salam contract has been carried out according to Islamic law or not. One of them is a local company engaged in clothing and fashion called Hope Apparel \& Clothing in Jombang Regency, East Java. The purpose of this study is to find out whether the Hope Apparel \& Clothing company has implemented the salam contract according to Islamic law correctly even though it is only based online. This research belongs to the classification of qualitative research that uses information retrieval methods with literature studies and interviews of the relevant sources. From this research, the result is Hope Apparel Clothing company has implemented the salam contract according to the Shari'a and its pillars, notwithstanding the implementation is based on technology.
\end{abstract}

Keywords: Salam contracts, electronic business, local company.

\begin{abstract}
Abstrak. Akad salam pada zaman modern telah diimplementasikan dengan cara yang berbeda, yakni menggunakan sistem online atau berbasis dalam jaringan. Banyak perusahaan yang menerapkan akad ini, namun masih belum diketahui apakah akad salam tersebut telah dijalankan sesuai syariat Islam atau tidak. Salah satunya adalah perusahaan lokal yang bergerak di bidang pakaian dan mode yang bernama Hope Apparel\&Clothing di Kabupaten Jombang, Jawa Timur. Tujuan dari penelitian ini yaitu untuk mengetahui apakah perusahaan Hope Apparel\&Clothing telah mengimplementasikan akad salam sesuai syariat Islam dengan benar meskipun hanya berbasis online. Penelitian ini termasuk jenis penelitian kualitatif yang menggunakan metode pengambilan informasi dengan studi pustaka dan wawancara narasumber yang bersangkutan. Dari penelitian ini diperoleh hasil yakni perusahaan Hope Apparel Clothing telah mengimplementasikan akad salam sesuai syariat dan rukunnya meskipun pelaksanaannya berbasis teknologi.
\end{abstract}

Kata kunci: Akad salam, e-bisnis, perusahaan lokal.

Received:

December 5, 2021

1st Revision:

January 4, 2022

Published:

January 4, 2022

Diterima:

5 Desember 2021

Direvisi:

4 Januari 2022

Dipublikasi:

4 Januari 2022 


\section{PENDAHULUAN}

Teknologi dan informasi pada era sekarang ini telah mengadaptasi berbagai macam bidang. Salah satunya terkait penerapan akad jual beli atau akad salam pada transaksi penjualan secara online yang tidak terlepas dari teknologi informasi dan electronic business. Maraknya perusahaan yang menerapkan akad salam dalam penjualannya namun pada beberapa aspek tertentu tak jarang terjadi hal menyimpang yang menyebabkan perusahaan tersebut tidak menjalankan akad salam secara sempurna. Padahal sebenarnya penerapan akad salam sesuai syariat Islam di era sekarang ini sangat berperan penting guna menjaga perkembangan serta keberkahan suatu bisnis dalam jangka panjang.

Strategi penerapan akad salam yang tepat dan efisien tentunya akan memberikan dampak yang positif sekaligus menambah nilai keberkahan dari segi spiritual bagi suatu perusahaan, konsumen yang membeli produk tersebut, dan juga mitra bisnis atau stakeholder yang bekerja sama. Dapat pula dijumpai beberapa perusahaan lokal yang mengalami disorientasi yakni diindikasikan dengan cenderung terfokus dalam menarget keuntungan pribadi dan golongan tanpa mengindahkan kaidah aturan-aturan pelaksanaan akad jual beli dalam syariat Islam. Hal itulah yang menyebabkan kegiatan penjualan yang sejatinya bernilai ibadah dan bersifat halal itu berubah menjadi ajang meraup keuntungan sebanyak-banyaknya bagi diri sendiri ataupun golongan dengan menggunakan berbagai modus tindak kriminal serta penipuan. Kasus tersebut seringkali dijumpai pada masyarakat Indonesia khususnya pada penjualan online. Para pengusaha bisnis lokal seringkali menyimpang secara etika dan moral. Sehingga, peran dari penerapan akad salam dalam jual beli online dengan baik dan sesuai syariat Islam adalah untuk menjaga nilai keberkahan dan mengurangi kemungkinan terjadinya perbuatan kriminal dalam lingkup perusahaan lokal yang ada di Indonesia.

Hasil yang diperoleh dari penelitian ini yakni perusahaan lokal Hope Apparel Clothing telah mengimplementasikan akad salam menggunakan perantara teknologi dengan baik dan sesuai syariat Islam. Penelitian ini difokuskan untuk menganalisis implementasi akad salam dalam jaringan (via online) dengan menggunakan variabel e-bisnis atau electronic business sebagai salah satu indikator yang dianalisis dalam penelitian ini. Peneliti memilih electronic business sebagai variabel penelitian karena peneliti menilai bahwa dalam proses menganalisis suatu hal maka diperlukan pandangan yang luas dari segala aspek objek penelitian sebagaimana electronic business merupakan segala proses bisnis yang melibatkan berbagai aspek mulai dari segmentasi konsumen, proses produksi, pemasaran, dan lainnya. Meskipun belum pernah ditemukan pada penelitian terdahulu terkait implementasi akad salam dalam electronic business, melainkan kebanyakan penelitian terdahulu yang cenderung berfokus pada variabel electronic commerce atau e-commerce sebagai variabel dalam analisis implementasi akad salam yang hanya membahas dalam segi pemasaran online melalui teknologi saja. Sehingga hal tersebut dijadikan sebagai unsur novelty atau pembaruan bagi penelitian ini dibandingkan dengan penelitian lainnya.

Di samping itu, penelitian ini sedikit berbeda dengan penelitian sebelumnya yang ditulis oleh Ashabul Fadhli yakni berjudul "Tinjauan Hukum Islam terhadap Penerapan Akad As-Salam dalam Transaksi E-Commerce” dan diterbitkan oleh Mazahib: Jurnal Pemikiran Hukum Islam Vol. 15 No. 1. Perbedaan yang mendasari penelitian ini dengan penelitian tersebut adalah terkait penggunaan variabel penelitian. Pada penelitian sebelumnya menggunakan variabel e-commerce sedangkan pada penelitian ini menggunakan variabel e-bisnis yang dianggap penulis lebih relevan karena pada e-bisnis mencakup proses bisnis mulai dari produksi, pemasaran, penjualan, hingga segmentasi konsumen dengan berbasis teknologi. Sedangkan, untuk persamaan dari kedua penelitian ini yakni terdapat pada topik bahasan atau topik penelitian, yakni terkait penerapan atau implementasi akad salam.

Penelitian ini juga mengambil rujukan dari penelitian terdahulu oleh Widiana dan Annisa yang bejudul "Menilik Urgensi Penerapan Pembiayaan Akad Salam pada Bidang Pertanian di Lembaga Kenangan Syariah di Indonesia." yang dipublikasikan oleh Jurnal Muqtasid: Jurnal Ekonomi Dan Perbankan Syariah Vol. 8 No. 2, yang di dalamnya berupa penerapan akad salam pada bidang pertanian, sedangkan pada penelitian kali ini, penulis menganalisis akad salam dalam bidang penjualan online. Selain itu, terdapat penelitian lain yang dijadikan rujukan penulis dalam melakukan penelitian ini, yakni berjudul "Analisis Transaksi Akad Salam dalam Jual Beli Online" karya Aly Akbar dan Mochammad Cahyo Sucipto oleh jurnal Eksisbank Vol. 2 No. 2 yang dipublikasikan pada tahun 2018, di dalamnya membahas terkait implementasi akad salam pada penjualan online khususnya menggunakan aplikasi Shopee secara umum tanpa ada penelitian spesifik terhadap suatu perusahaan. Hal tersebut berbeda dengan penelitian ini yang berfokus pada satu perusahaan, yakni Hope Apparel Clothing. 
Penelitian ini juga mengutip teori-teori dari tokoh ternama yang digunakan sebagai kajian pustaka yang dijadikan suatu landasan teoretik bagi pembahasan dalam setiap sub bab yang mendasari penelitian ini didapatkan dari berbagai sumber pustaka salah satunya yaitu karya Ramunè \& Giedre berjudul "Theoretical Framework of E-Business Competitiveness" yang di dalamnya terdapat teoriteori yang digagas oleh Pilinkiene dan Elektroninio Verslo Vadovas. Kajian pustaka yang telah disebutkan di atas dipilih penulis karena dinilai relevan dengan topik pembahasan sekaligus dapat dijadikan sebagai landasan teoretik pada penelitian ini.

Hasil yang diperoleh dari penelitiian ini ditujukan agar dapat memberi manfaat bagi perkembangan penelitian selanjutnya terkait akad salam maupun bidang keilmuan lain yang dapat mengambil manfaat dari penulisan ini. Selain itu, manfaat dari penelitian ini yakni agar pembaca dapat menambah wawasan dan ilmu khususnya terkait penerapan akad salam berbasis teknologi.

\section{KAJIAN LITERATUR}

\section{Akad Salam}

1. Pengertian Akad Salam

Pada hakikatnya, akad salam dapat diartikan sebagai sebuah proses pemberian dana di awal, lalu penjual berkewajiban untuk mengirimkan barang atau objek pembelian tersebut kepada pembeli yang berhak menerima barang tersebut.Akad salam merupakan salah satu jenis jual beli yang dikecualikan dari

larangan menjual sesuatu yang tidak ada atau barang yang bukan termasuk hak milik penjual.Akad salam dapat diklasifikasikan sebagai suatu penjualan barang yang terutang dan ditentukandengan pemberian imbalan harga (Widiana \& Annisa, 2017, p. 97). Di samping itu, akad salam juga termasuk kontrak pertukaran atau substitusi yang menetapkan kewajiban mengikatpada penjual yang harus dipenuhi olehnya dengan penyerahan barang jualan saat pembayaran telah dilunasi oleh konsumen, sehingga terjadilah transaksi yang melibatkanbaik jual beli maupun pinjam meminjam. Pada era modernisme, akad salam semakin berkembang dan beradaptasi dengan perkembangan teknologi dan internet sehingga akad salam dapat diaplikasikan ke dalam bentuk digital.

2. Dasar Hukum Akad Salam

Menurut aturan dan syariat agama Islam, akad jual beli khususnya akad salam telah diatur salah satunya yang termuat pada Al-Quran surat al-Baqarah (2): yang artinya : "Wabai (engkau) orang-orang beriman, jikalau engkau melakukan (transaksi) muamalah bukan melalui tunai dalam kurun periode yang telah disepakati, maka sebaiknya engkau mencatatkannya. Dan hendaknya orang yang bertugas mencatatkannya di antara kamu mencatatkannya dengan benar. Dan janganlah orang yang bertugas mencatat tersebut tidak bersedia mencatatnya sebagaimana Allah telah mengajarkan pada dirinya, maka hendaklah dirinya mencatat, dan sebaiknya pihak yang berbutang itu mengimlakkan yang akan dicatat tersebut, dan hendaklah dirinya bertaqwa pada Allah sebagai Tuhannya, dan janganlah dirinya mengurangi (pembayaran) butangnya sedikitpun. Apabila pihak yang berbutang tersebut (digolongkan sebagai) orang yang memiliki kelemahan akal atau lemah (kondisinya) atau diriny sendiri tak memungkinkan untuk mengimlakean, maka bendaknya wali darinya yang mengimlakean dengan penub kejujuran."

Ayat tersebut berperan sebagai landasan teori atau dasar hukum yang kuat terkait akad salam. Hal tersebut karena pada ayat di atas mengindikasikan tentang anjuran untuk mencatat tiap-tiap transaksi atau muamalah yang dilakukannya bukan secara tunai (salah satunya yakni akad salam). Allah SWT pun memerintahkan para umat manusia agar mencatatkan transkasi tersebut dengan sejujur-jujurnya tanpa ada rekayasa apapun demi meraup keuntungan sebanyakbanyaknya untuk dirinya pribadi. Pada akad salam, ayat al-Qur'an tersebut berperan besar dalam mengatur berjalannya akad salam. Meskipun untuk era modern ini, akad salam telah diadaptasi dengan metode baru sesuai kecanggihan teknologi, namun tetap harus mematuhi ayat al-Qur'an tersebut sebagai pedoman dasar bermuamalah atau bertransaksi yang dihalalkan dan diridhoi oleh 
Allah SW'T.

3. Teori atau Gagasan Ulama

Di samping ayat al-Qur'an tersebut, akad salam juga didasarkan pada teori atau gagasan ulama-ulama terkemuka yakni dalam pandangan Imam Hanafi akad salam yakni ditakrifkan sebagai jual beli untuk jangka waktu, seperti jual beli suatu barang yang dibeli dan dibayar untuk di muka. Mereka juga melihatnya sebagai membeli sesuatu yang ditunda sebagai gantinya untuk sesuatu yang diberikan pada saat ini, atau sebagai menjual waktu yang akan datang untuk waktu itu sekarang. Jadi, itu adalah kontrak yang melibatkan sesuatu yang layak untuk dijual, yaitu ditentukan, yang terutang; pengirimannya ditunda, dengan imbalan harga yang dikumpulkan pada sesi kontrak. Imam Syafii menakrifkan akad salam sebagai penjualan sesuatu yang telah ditentukan dengan berhutang. Mereka melihatnya sebagai hutang dan karena itu melakukannya tidak membuat suatu kondisi bahwa periode di mana objek penjualan akan dikirimkan (Al Zaabi, 2010, p. 93).

Gagasan lain yakni datang dari Imam Maliki yang menakrifkan bahwa akad salam sebagai penjualan sesuatu yang terutang dan ditentukan dengan imbalan harga, sedangkan pengiriman barang ditunda untuk sementara waktu dengan mengizinkan penundaan transfer harga kepada pembeli untuk jangka waktu tidak lebih dari tiga hari. Bagi mereka, akad salam adalah hanya kontrak pertukaran atau substitusi yang menetapkan kewajiban yang mengikat pada penjual yang harus dipenuhi olehnya dengan penyerahan barang jualan, bukan untuk uang siap pakai diserahkan dalam pertukaran untuk sesuatu yang didefinisikan sebagai hutang dengan jangka waktu yang diketahui (Al Zaabi, 2010, p. 94). Mereka juga menilai akad salam sebagai proses transaksi membeli sesuatu yang ditunda sebagai gantinya untuk sesuatu yang diberikan pada saat ini, atau sebagai proses transaksi yakni menjual di waktu yang akan datang untuk waktu sekarang.

Jadi, itu adalah kontrak yang melibatkan sesuatu yang layak untuk dijual, yaitu ditentukan, yang terutang; pengirimannya ditunda, dengan imbalan harga yang dikumpulkan pada sesi kontrak. Syarat terlampir di sini, yaitu bahwa harga (modal di muka) diserahkan pada saat kontrak, menghindari transaksi terlarang satu utang untuk utang lain, atau dijanjikan ditukar dengan sesuatu yang terutang/dijanjikan.

Di samping itu terdapat teori dari Ibn Qudamah (1997) yang menyatakan bahwa:

"As for consensus, Ibn al-Mundhir asserts that all known authorities on the subject have upheld salam. He also claims that salam is "facilitation and an extension that closes up the door against usury. That is because the owner of business [the seller] needs financing for his farm, goods or trade while for the salam owner [the buyer] there is the benefit of investing his money and making good (halal) profits."(Al Zaabi, 2010, p. 96).

Pada gagasan tersebut secara tidak langsung telah mendeskripsikan akad salam dalam transaksi jual beli sebagai sebuah proses pemberian dana di awal, lalu penjual berkewajiban untuk mengirimkan barang atau objek pembelian tersebut kepada pembeli yang berhak menerima barang tersebut. Terkait skema pelaksanaan akad salam menggunakan sistem electronic business dapat dilihat pada gambar 1 berikut.Berikut teori yang digunakan dalam penelitian ini:

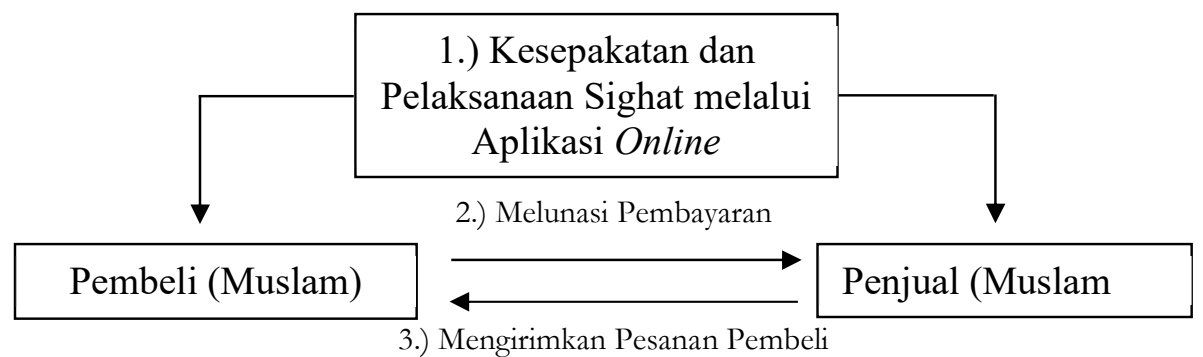

Gambar 1. Skema Akad Salam Menggunakan Sistem E-Bisnis 


\section{METODE PENELITIAN}

Pada penelitian ini penulis menganalisis secara kualitatif serta menggunakan pendekatan normatif, yakni sebuah pendekatan yang mengkaji persoalan didasarkan pada ketetapan norma agama atau teori dari tokoh-tokoh terkait syariat Islam dalam tujuan untuk menilai kebenaran pada persoalan yang dikaji.

Teknik pengumpulan informasi dan teori-teori ilmiah yang disampaikan beberapa tokoh yang relevan dengan bidang ilmu yang dikaji dalam penelitian inidengan menggunakan cara studi pustaka melalui berbagai sumber literasi dan wawancara narasumber yang bersangkutan, yakni Devana Gema Falesta selaku pemilik perusahaan Hope Apparel\&Clothing melalui kunjungan langsung ke tempat usaha yang berlokasi di Jalan Laksda Adi Sucipto Nomor 57, Denanyar, Kabupaten Jombang, Jawa Timur.

Pada penulisan artikel ini, analisis hasil penelitian yang dipilih penulisadalah bersifat induktif atau kualitatif, yakni dengan cara memilih rumusan masalah yang akan dikaji, mengumpulkan informasi dan data sekunder, mengembangkan gagasan teori dari berbagai teori tokoh bersangkutan dan disertai pula dengan pengumpulan informasi yang diperoleh dari penelitian lapangan, serta menganalisis implementasi dari rumusan masalah yang dikaji.

\section{HASIL PENELITIAN DAN PEMBAHASAN}

\section{Aplikasi E-Bisnis dalam Penerapan Akad Salam}

E-Business (electronic business) adalah setiap proses yang dilakukan oleh perusahaan melalui jaringan yang diperantarai oleh komputer. Proses yang dijalankan mencakup proses bisnis yang berfokus pada produksi, pelanggan, dan internal atau manajemen. Menurut Pilinkiene (2013), ebisnis dapat digambarkan sebagai seperangkat proses dan alat yang memungkinkan perusahaan menggunakan teknologi informasi berbasis internet untuk menjalankan bisnis secara internal dan eksternal. Akhir-akhir ini investasi perusahaan ke dalam infrastruktur e-bisnis dan solusi e-bisnis telah dipertimbangkan menjadi sangat penting bagi perusahaan yang ingin bersaing dengan sukses di berbagai industri dan pasar (Ramuné \& Giedré, 2015, p. 734).

Aplikasi e-bisnis dianggap sebagai mekanisme yang memungkinkan untuk meningkatkan kompetensi penjualan, memberikan perusahaan peluang baru untuk mengirimkan barang dan jasa sekaligus menambah nilai jual melalui peningkatan efisiensi dan efektivitas rantai pasokan. E-bisnis memperkenalkan peluang yang baru bagi perusahaan untuk bersaing di pasar global dengan cara meningkatkan daya saing perusahaan berupa peningkatan teknologi informasi dan komunikasi yang inovatif di berbagai perusahaan, yang dapat menghubungkan mitra dan pelanggan. E-bisnis, khususnya perdagangan berbasis elektronik, memiliki potensi untuk mengubah kegiatan ekonomi dan lingkungan sosial. Topik e-bisnis dan daya saing menarik banyak minat di komunitas ilmiah dan telah dianalisis secara luas selama dekade terakhir. Salah satunya adalah teori konsep e-bisnis gagasan Elektroninio Verslo Vadovas yang dapat digambarkan sebagai:

1) Automatisasi proses bisnis internal dan eksternal dalam jaringan komputer;

2) Aplikasi teknologi dan informasi yang inovatif baik dalam perusahaan maupun di luar perusahaan untuk meningkatkan daya saing;

3) Nilai pelanggan tambahan melalui jaringan yang dimediasi komputer;

4) Strategi kompetitif yang kritis (Ramunè \& Giedré, 2015, p. 735).

Konsep keunggulan kompetitif dan daya saing memiliki tradisi panjang dalam manajemen strategis literatur ilmiah dan masih menjadi fokus karya penelitian akademis. Berbagai aspek daya saing dan faktor-faktor yang mempengaruhi daya saing dalam manajemen strategis literatur ilmiah yang masih menjadi fokus karya penelitian akademis. Terlepas dari studi signifikan yang dilakukan di bidang e-bisnis dan daya saing perusahaan, pada dasarnya hal tersebut membutuhkan lebih banyak penelitian komprehensif dalam mengeksplorasi daya saing e-bisnis dan indikator yang memungkinkan untuk mengukur kinerja e-bisnis dan kapasitas kompetitif pada tingkat abstraksi yang berbeda. 
Dalam aplikasi e-bisnis, penerapan akad salam dapat berupa proses internal maupun eksternal dalam jaringan komputer, proses produksi barang pesanan akad salam hingga proses pendistribusian barang melalui sistem online, proses segmentasi pasar dan konsumen, serta peningkatan layanan aplikasi yang menyediakan fitur-fitur pendukung berjalannya akad salam secara efisien. Selain itu, penerapan akad salam dalam aplikasi e-bisnis juga mencakup lingkup manajemen pemasaran dan peningkatan daya saing antar perusahaan yang berbasis online dengan tetap menegakkan syariat Islam serta tidak meninggalkan rukun atau syarat sah dari akad salam itu sendiri.

\section{Implementasi Akad Salam pada Perusahaan Hope Apparel Clothing}

Dalam penjualan khususnya yang berbasis online, perusahaan yang berniat untuk menerapkan praktek akad salam secara sempurna pada usahanya sebaiknya memperhatikan kesesuaian rukun akad salam dengan realita yang diimplementasikan pada perusahaannya. Sejalan dengan hal itu, terdapat sejumlah ulama' fiqh yang beranggapan bahwa sebuah kesepakatan dalam hal jual beli yang serupa dengan akad salam, bilamana kesepakatan itu telah melengkapi rukun akad salam maka dapat dikatakan sah dan termasuk ke dalam jual beli salam. Terkait rukun yang dimaksud yakni yang pertama adalah pihak yang terlibat dalam kesepakatan jual beli yakni pembeli atau muslam, serta penjual atau muslam 'alaih, yang kedua adalah harta atau modal (ra'sul ma'al as-salam), yang ketiga adalah barang atau objek transaksi (muslam fiib) dan yang keempat adalah ucapan ijab qabul (sighat) (Djamil, 2012, p. 133).

a) Pihak-pihak yang Terikat dalam Kesepakatan Jual Beli (Subyek).

Penjual (muslam 'alaib) dan pembeli (muslam) dapat diklasifikasikan ke dalam kategori pihak-pihak yang terikat dalam kesepakatan jual beli, yakni khususnya pada pembahasan kali ini ialah terkait jual beli dengan akad salam. Menurut pendapat Devana Gema Falesta, selaku pendiri perusahaan Hope Apparel Clothing, penjual ialah penyelenggara suatu akad atau kesepakatan jual beli dengan cara mentransaksikan obyek dagangannya kepada pihak pembeli atau buyer dengan perantaranya yakni berbasis dalam jaringan internet (sistem online). Selaku pihak penjual, maka tentunya berkewajiban untuk mempunyai asset modal yang berupa obyek dagangan dengan dapat dipertanggungjawab kan terkait kebenaran sekaligus keberadaan produk itu. Di samping itu pula, juga harus dapat diverifikasi keabsahan kepemilikan sah produk atau obyek dagangan tersebut. Hal tersebut dilakukan agar pihak penjual dapat diakui secara legal (Falesta, 2021).

Sedangkan, pembeli ialah pihak, yang biasanya perseorangan dalam sebuah kesepakatan jual beli dengan tujuan untuk memenuhi kebutuhan atau keinginannya melalui perantara berbasis dalam jaringan internet (sistem online). Di samping itu, pihak-pihak yang terlibat dalam kesepakatan jual beli bukanlah hanya sebatas pembeli dan penjual saja. Melainkan, tanpa disadari sebenarnya peran dari pihak lain juga dapat diklasifikasikan sebagai subyek dalam kesepakatan jual beli. Pihak lain tersebut yakni orang yang mewakili proses kesepakatan jual beli atau transaksi yang dapat berasal dari pihak pembeli maupum pihak penjual. Namun, status perwakilan tersebut bukanlah hal yang wajib dipenuhi dalam rukun akad salam. Hal tersebut karena sifat dari penggunaan wakil adalah tidak mutlak. Bilamana suatu kesepakatan jual beli sangat membutuhkan adanya pihak wakil, maka tidak masalah jika subyek transaksi tersebut diwakilkan. Namun, dengan adanya sistem perwakilan tersebut seharusnya tidak menggugurkan jalannya transaksi agar tujuan utama dari proses transaksi atau kesepakatan jual beli tersebut dapat tetap berlangsung sesuai harapan masing-masing pihak yang bersangkutan.

Pada saat berjalannya akad salam, kedua belah pihak yakni muslam dan muslam 'alaib diharuskan untuk saling ridho dan rela terhadap kewajiban serta hak yang didapatkan. Hal tersebut karena pada sejatinya, kerelaan merupakan salah satu asas utama yang perlu diperhatikan dalam melaksanakan akad salam. Apabila kedua belah pihak ataupun salah satu pihak merasa keberatan dan tertekan atas akad tersebut, maka dapat menggugurkan keabsahan akad salam tersebut. Pada kesepakatan jual beli online, biasanya terdapat beberapa contoh kasus terkait kerelaan subyek akad. Misalkan konsumen menginginkan barang yang 
berwarna putih sedangkan penjual memberi tahu bahwa stok persediaan hanya tersisa warna hijau, namun karena konsumen tersebut sudah terlanjur membayar maka terpaksa barang yang dikirimkan berbeda dengan keinginan konsumen. Sehingga, tentunya akan muncul perasaan terpaksa, tidak ikhlas, dan tidak puas atas jasa layanan tersebut. Oleh sebab itu, kegiatan jual beli online juga datang memberikan solusi yakni dengan fitur refund yang dapat dirupakan uang atau barang yang akan diberikan kepada konsumen sebagai bentuk ganti rugi atas berjalannya akad salam yang tidak melibatkan unsur kerelaan atau keikhlasan kedua belah pihak maupun hanya sepihak saja. Hal tersebut juga termuat dalam QS. an-Nisa (4):29 sebagai berikut:

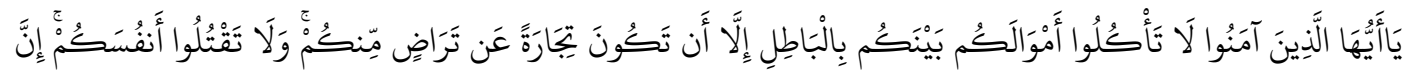
اللََّ كَانَ بِكُْْ رَحِيمًا

Terjemahnya: "Wahai orang-orang beriman, jangan engkaumakan harta sesamamu dengan carabathil, kecuali melalui perdagangan yang berdasar atas perasaan saling suka di antara kalian. Dan jangan engkau membunuh dirimu, Sesungguhnya Allah Maha Penyayang kepada engkau.Pada hakikatnya perjanjian tersebutialah kesepakatan antar kedua pibak dan akibat bukumnya ialah apa yang telah mereka janjikan."(QS. an-Nisa: 29)

b) Harta atau Modal (Ra'sul ma'al As-Salam)

Pada perusahaan Hope Apparel Clothing yang menggunakan transaksi akad salam berbasis dalam jaringan, penyerahan harta atau metode pembayaran dilakukan secara perwakilan yang berupa payment gateway, yakni fitur dalam aplikasi jual beli online yang menjadi perwakilan dari alat pembayaran atau ra'sul ma'al as-salam dengan fungsi melisensikan payment process yang dapat dibayarkan melalui kerja sama dengan berbagai perbankan maupun berbagai perusahaan dompet digital selaku selaku issuer dan acquirer. Para perantara yang menjadi perwakilan tersebut bertugas untuk memperantarai akad salam yang berlangsung antara perusahaan Hope Apparel Clothing selaku penyedia barang atau penjual dengan pihak konsumen atau customer sebagai pembeli. Perantara tersebut memiliki peran sebagai fasilitator pendukung yang menjamin sebuah validitas, kepercayaan, serta data administratif pada saat pengguna melakukan akad salam via online. Di samping itu pula, para fasilitator perantara yang dipilih oleh perusahaan Hope Apparel Clothing tersebut diupayakan selalu menjaga keamanan dan kerahasiaan data privasi pengguna saat akad salam berlangsung. Maka dari itulah, para fasilitator perantara itu dapat diqiyaskan sebagai pihak saksi dari sebuah akad salam via online tersebut.

Menurut gagasan yang ditegaskan oleh ulama fiqh, sebuah akad (khususnya kesepakatan jual beli) bisa menjadi lebih sempurna dengan diberikannya bukti tulisan yang dapat berupa korenpondensi bilamana kedua pihak (yakni penjual dan pembeli) kondisinya tidak bertempat di satu majelis akad yang sama. Akan tetapi, bilamana kedua pihak yakni pembeli dan penjual menghadiri akad dalam satu majelis yang sama, namun dengan kondisi mengalami kesukaran apabila akad dilakukan secara tertulis, sehingga diwakilkan seorang pihak yang bertanggungjawab mengutarakan tujuan akad atau memberi tahu secara lisan, maka hukumnya boleh.

c) Ucapan Ijab Qabul (Sighat)

Pada sebuah akad dalam hukum Islam, tentunya harus menggenapi dan menyempurnakan rukun di dalamnya, yakni salah satu rukun terpenting dalam segala macam akad ialah ijab qabul atau sighat. Pada perusahaan Hope Apparel Clothing yang mengimplementasikan akad salam dalam bentuk digital atau berbasis teknologi, pelaksanaan sighat diqiyaskan berupa fasilitas yang terdapat pada aplikasi penjualaan online. Perlu diketahui bahwa sejatinya sighat harus berdasarkan keikhlasan hati kedua belah pihak tanpa adanya pemaksaan, maka bentuk implementasinya dalam sebuah aplikasi tersebut, para calon konsumen dapat memilih produk, jenis produk, metode pembayaran, sistem pembayaran, 
metode dan sistem pengiriman, serta masih banyak lainnya. Transakasi yang dilakukan melalui e-commerce atau e-business ini, secara syar'i jelas sah dilihat dari aspek terjadinya ijab dan qabul (Akbar \& Sucipto, 2018, p. 16).

Apabila terdapat hal-hal yang perlu dikonsultasikan dan disepakati, maka calon konsumen tersebut dapat menghubungi admin Hope Apparel Clothing melalui fitur pesan yang tersedia sebelum pembayaran. Sehingga, pelaksanaan rukun akad salam terkait sighat (ucapan ijab dan qabul) dapat terimplementasi dengan baik karena kedua pihak telah saling sepakat meskipun diwakilkan dengan bentuk fitur-fitur dalam aplikasi. Selain itu, apabila terdapat keterlambatan pengiriman, kecacatan pada produk yang disebabkan karena kelalaian pihak ekspedisi, atau persoalan lainnya juga dapat dikonsultasikan secara online dan apabila dibutuhkan, konsumen bisa mengajukan refund baik dalam bentuk dana ataupun dalam bentuk barang. Sehingga, kepuasan konsumen tetap terjaga dan pihak Hope Apparel Clothing terhindar dari gharar atau penipuan.

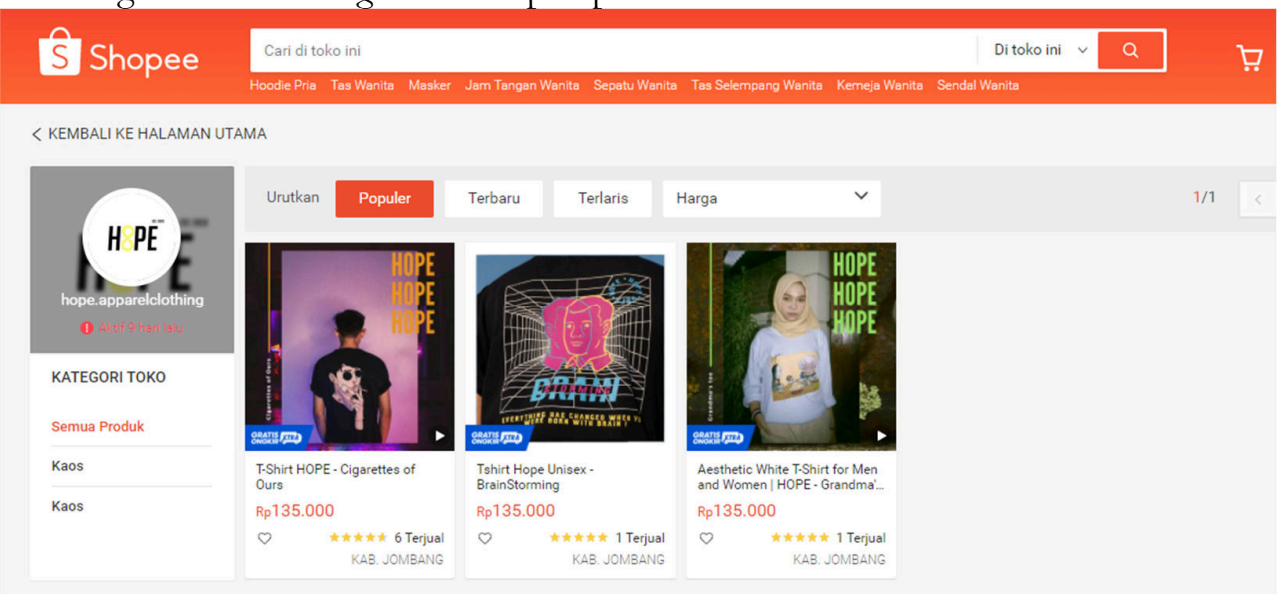

Gambar 1. Tampilan Aplikasi E-Bisnis Perusahaan Hope Apparel Clothing Sumber: Dokumentasi pribadi penulis

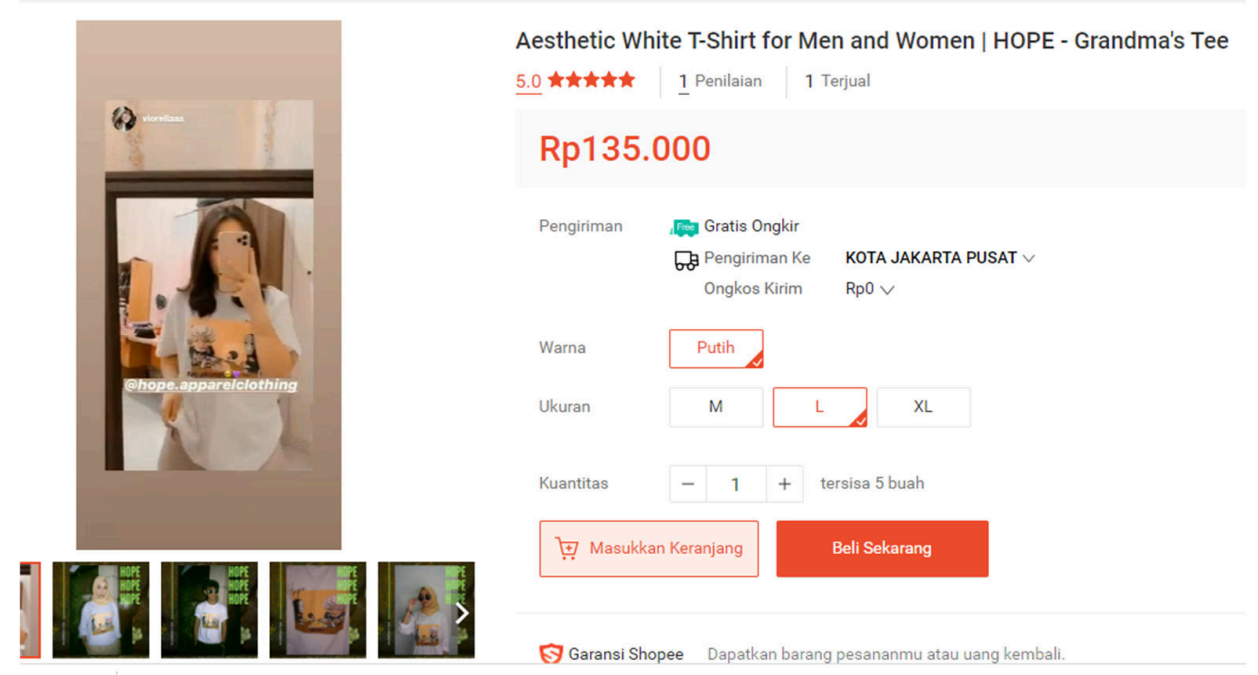

Gambar 2. Pelaksanaan sighat dengan cara pembeli memilih objek transaksi (muslam fiih) sesuai keinginan berdasarkan warna, kuantitas, dan ukuran pakaian dilengkapi dengan fitur refund pada bagian kanan bawah bertuliskan Garansi Shopee apabila pesanan tidak sesuai dengan keinginan pembeli.

Sumber: Dokumentasi pribadi penulis

Menurut gagasan beberapa fuqaha, terdapat perbedaan pendapat terkait tempat pelaksanaan atau majlis akad salam. Sejumlah ulama fiqih menganggap bahwa ijab dan qabul diwajibkan berada di majelis yang sama agar tidak menggugurkan keabsahan akad salam. 
Pendapat itu salah satunya disepakati oleh ulama' mazhab Malikiyyah dan Syafi'iyyah. Di sisi lain, ada sejumlah ulama fuqaha yang beranggapan bahwa majelis akad hanyalah rukun formalitas saja. Oleh sebab itu, sighat tetap sah meskipun dilakukan di luar majelis akad (Haroen, 2007, pp. 130-131).

Hal serupa juga didukung oleh pendapat ulama kontemporer yang bernama Wahbah Zuhayli. Beliau beranggapan bahwa majelis akad tidaklah lagi mewajibkan pertemuan para pihak yang bersangkutan secara fisik bilamana sarana yang menghubungkannya tersedia. Hal tersebut diibaratkan seperti sistem perpanjangan tangan dalam pelaksanaan akad. Dalam riwayatnya, diketahui bahwa Nabi SAW pernah melakukan hal tersebut manakala beliau bertanggungjawab menangani dagangan milik isterinya, Khadijah (Perwataatmadja \& Tanjung, 2007, p. 127). Sepanjang hidupnya, Nabi SAW menegaskan bahwa perdagangan jenis ini termasuk halal dan sah. Di samping termasuk sebagai kebutuhan bagi pihak penjual, adanya keterbatasan yang menyebabkan terhalangnya penyerahan objek akad secara langsung, sehingga akad salam diperbolehkan (Zuhaily, 2011, p. 3602).

d) Barang atau Obyek Transaksi (Muslam Fiih)

Pada hakikatnya, yang disebut sebagai objek transaksi yakni berwujud barang dagangan yang dapat diproduksi dan dipasarkan hingga ke tangan pembeli atau konsumen. Sebelum melakukan proses pembayaran pada jual beli online yang diterapkan oleh perusahaan Hope Apparel Clothing, tentunya obyek yang diperdagangkan sudah tersedia dan sesuai keinginan konsumen seperti yang telah disepakati bersama dalam akad yang berwujud aplikasi online. Konsumen dari perusahaan Hope Apparel Clothing pun dapat memilih barang keinginannya sesuai dengan stok yang masih tersedia tanpa adanya unsur penipuan atau sebagainya. Setelah itu, apabila konsumen telah memilih produk atau barang yang diinginkan, maka konsumen berkewajiban untuk segera melunasi pembayaran dengan menyerahkan ra'sul ma'al as-salam yang dirupakan payment gateway. Lalu, perusahaan Hope Apparel Cloting berkewajiban untuk segera mempersiapkan obyek transaksi atau barang-barang pesanan tersebut untuk segera dikirimkan sesuai alamat yang telah tertulis pada data administratif aplikasi online.

Apabila sesuatu yang tidak dapat dipastikan perihalnya (obyek) dan tidak diketahui kelanjutannya maka dapat diklasifikasikan ke dalamtransaksi gharar. Misalnya ditemui beberapa kondisi yang menyebabkan cacat hukum dalam pelaksanaan obyek akad. Agar terhindari dari kerusakan obyek akad, maka dalam setiap transaksi e-commerce harus memiliki ketentuan yakni obyek telah ada pada waktu akad diadakan, serta obyek dapat menerima hukum akad. Dalam transaksi e-commerce misalnya, barang yang diperjual belikan harus merupakan benda bernilai bagi pihak-pihak yang mengadakan akad jual-beli. Minuman keras bukan benda bernilai bagi kaum muslimin, maka tidak memenuhi syarat menjadi obyek akad jual beli. Di samping itu, obyek harus dapat ditentukan dan diketahui dengan jelas, serta obyek dapat diserahkan. Pada konteks ini obyek akad tidak harus dapat diserahkan seketika, akan tetapi menunjukkan bahwa obyek tersebut benar-benar ada dalam kekuasaan yang sah pihak bersangkutan. Ini juga berlaku dalam akad as-salam yang diharuskan adanya pencatatan dan persyaratan khusus (Fadhli, 2016, p. 13).

Menurut pendapat Devana Gema Falesta, selaku pemilik perusahaan Hope Apparel Clothing, hingga masa ini pun masih belum dituliskan secara resmi terkait penjualan menggunakan sistem e-bisnis sekaligus akad salam yang seharusnya ditetapkan oleh fatwa Dewan Syariah Nasional dan Majelis Ulama Indonesia (Falesta, 2021). Akan tetapi, syariat hukum pelaksanaan akad salam secara online menggunakan sistem e-bisnis ini masih dapat dirujukkan pada transaksi elektronik lainnya, seperti penggunaan Letter of Credit yang sistemnya hampir serupa, Majelis Ulama Indonesia memutuskan hukum kebolehan pada transaksi jasa yang dilakukan oleh Perbankan Syariah untuk memfasilitasi transaksi ekspor kepada nasabah. Penetapan hukum tersebut tercantum dalam Fatwa DSN Nomor: 34/DSNMUI/IX/2002 tentang Letter of Credit Ekspor Syariah. Dengan syarat yakni segala macam mekanisme pelaksanaannya harus dilaksanakan menurut syariat Islam dengan benar. Tak hanya itu, melainkan terdapat beberapa macam transaksi lainnya seperti penjualan dan pembelian saham di pasar regular bursa efek. Transaksi tersebut menggunakan sistem kontrak jual beli efek yang dibuat oleh anggota bursa efek menurut persyaratan yang telah 
disepakati. Perdagangan tersebut termasuk ke dalam sistem jual beli online yang dilakukan dalam satu majelis dengan mekanisme yang menjamin terpenuhinya hak sekaligus kewajiban seluruh pihak yang bersangkutan (Fadhli, 2016, p. 16).

\section{KESIMPULAN DAN SARAN}

\section{Kesimpulan}

Menurut hasil pembahasan dan analisis yang telah dipaparkan pada penelitian ini, dapat diambil kesimpulan yakni akad salam merupakan suatu akad kesepakatan jual beli yang ditandai dengan sistem pembayaran dahulu dan pengiriman barang kemudian. Namun, perlu diketahui bahwa sejatinya yang menjadi objek tersebut haruslah barang yang sudah pasti tersedia agar tidak menimbulkan adanya gharar. Di samping itu, perkembangan electronic business pada era ini yang mulai berkembang pesat sudah semestinya dibarengi dengan penerapan akad salam yang sesuai syariat Islam. Salah satu perusahaan yang mengimplementasikan akad salam pada electronic business tersebut ialah perusahaan Hope Apparel Clothing. Perusahaan tersebut telah menjalankan akad salam sesuai dengan rukun-rukunnya yakni segmen pembeli (muslam) dan penjual (muslam 'alaih) yang memenuhi syarat, lalu yang kedua adalah harta atau modal (ra'sul ma'al as-salam) dengan sistem pembayaran yang telah sesuai syariat Islam, lalu yang ketiga adalah barang atau objek transaksi (muslam fiih) yang sudah disediakan sehingga tidak terdapat unsur gharar, dan yang terakhir adalah sighat yang dirupakan dengan fitur aplikasi online.

\section{Saran}

Di dalam penelitian ini, masih terdapat beberapa kekurangan yakni cakupan penelitiannya yang kurang luas, karena penulis masih berfokus untuk menganalisis satu lingkup rumusan masalah saja, yakni analisis penerapan akad salam hanya dalam sudut pandang electronic business. Sehingga, penulis berharap agar penelitian selanjutnya dapat menjadi lebih baik dengan cara melakukan penelitian yang lebih luas cakupannya agar diperoleh hasil yang lebih maksimal. Di samping itu, terkait akad salam pada zaman modern ini diharapkan agar tetap berjalan sesuai dengan prinsip-prinsip dan rukunrukun syariah sekaligus membarengi dengan perkembangan teknologi yang semakin memudahkan urusan manusia.

\section{Daftar Pustaka}

Akbar, A., \& Sucipto, M. C. (2018). Analisis Transaksi Akad Salam dalam Jual Beli Online. EKSISBANK, 2(2), 11-17. https://doi.org/https://doi.org/10.37726/ee.v2i2.47

Al Zaabi, O. S. (2010). Salam Contract in Islamic Law: A Survey. Review of Islamic Economics, 14(2), 91-122. http://citeseerx.ist.psu.edu/viewdoc/download?doi=10.1.1.1040.5771\&rep=rep1\&type=pdf

Djamil, F. (2012). Penerapan Hukum Perjanjian dalam Transaksi di Lembaga Kenangan Syariah. Sinar Grafika. https://onesearch.id/Record/IOS3504.libra-063402116000128

Fadhli, A. (2016). Tinjauan Hukum Islam terhadap Penerapan Akad As-Salam dalam Transaksi ECommerce. Mazabib, 15(1), 1-19. https://doi.org/: http://dx.doi.org/10.21093/mj.v15i1.589

Falesta, D. G. (2021, October 2). Pemilik Usaha Hope Apparel\&Clothing. Interview.

Haroen, N. (2007). Fiqih Muamalah. Gaya Media Pertama. https://onesearch.id/Record/IOS3354.slims-15345

Perwataatmadja, K., \& Tanjung, H. (2007). Bank Syariah: Teori, Praktek dan Perannya. Transmedia. https:/ /opac.perpusnas.go.id/DetailOpac.aspx?id=434411

Ramune, Č., \& Giedrè, S. (2015). Theoretical Framework of E-Business Competitiveness. Procedia: 
$\begin{array}{llll}\text { Social and } & \text { Behavioral } & \text { Science, } & \text { 213(1), }\end{array}$ https://doi.org/https://doi.org/10.1016/j.sbspro.2015.11.528

Widiana, \& Annisa, A. A. (2017). Menilik Urgensi Penerapan Pembiayaan Akad Salam pada Bidang Pertanian di Lembaga Keuangan Syariah di Indonesia. Muqtasid: Jurnal Ekonomi Dan Perbankan Syariah, 8(2), 88-101. https://doi.org/http://dx.doi.org/10.18326/muqtasid.v8i2.88-101

Zuhaily, W. (2011). Al-figh al-Islami wa Adillatubu (5th ed.). Gema Insani. https:/ /opac.perpusnas.go.id/DetailOpac.aspx?id=118843 